Academic freedom and security conflict

Challenge to access rule

\section{from Stanford}

\section{Washington}

The National Academy of Sciences (NAS) moved quickly last week to disengage itself from efforts by the US State Department to restrict ideas that American university research workers are allowed to discuss with visiting Soviet scientists.

The academy was responding to complaints that, in administering the exchange programme between scientists from the two countries, NAS officials have been routinely passing on instructions from the State Department about limitations to be placed on particular individuals.

Scientists at Stanford University in California objected earlier this month to the academy when such a letter was received covering the proposed visit of $\mathrm{Dr}$ Nikolay V. Umnov, an expert in robotics and walking machines, to the university's department of mechanical engineering. It was to be one of a series of visits which the Soviet scientist had requested to universities throughout the country.

NAS officials told the university that $\mathrm{Dr}$ Umnov's visit had been approved by the State Department, but only under certain conditions. He was not to be allowed access to data about programming techniques for robots, nor was he to make any industrial visits to companies with Defense Department contracts. The State Department has said that, unless waivers were negotiated with the Department of Defense, Dr Umnov was not to be allowed access to unpublished results of Department of Defense sponsored research even if this was unclassified. The academy passed these instructions on to the five universities Dr Umnov was to visit.

Following a complaint from Dr Bernard Roth, a professor in the department of engineering the university's dean of research, Dr Gerald J. Lieberman, wrote back saying that Stanford was prepared to sponsor Dr Umnov's visit, but refused to accept the conditions imposed by the State Department.

"We are not willing to accept responsibility for Dr Umnov's actions either on or off the campus - during his visit to Stanford," Dr Lieberman wrote. $\mathrm{He}$ added that the NAS memorandum was a surprise, saying that "we believe that the best interests of American science and technology are served by open exchanges of university research activities and hope that the academy will visibly support universities' position on this critical issue".
A spokesman for the academy said last week that it had been decided to suspend the simple transmission of restrictions required by the State Department until the governing board of the National Research Council and the council of the academy "has had a chance to examine the whole thing from the policy point of view". Both bodies meet next month.

As efforts have been made to tighten restrictions on visiting scientists, concern about the implications have been growing on US campuses. A year ago, Stanford sent a letter on behalf of the presidents of five major research universities to the Department of Defense, Commerce and State, complaining that such a tightening could seriously hamper the work of the scientific community. The president of the academy, Dr Frank Press, has also expressed publicly his concern about suggestions from the deputy director of the Central Intelligence Agency, about the need for greater caution in the publication of research results in fields such as lasers and computer software.

Last year a group set up jointly by the National Security Agency and the American Council on Education agreed to establish a system by which research results in cryptography could be voluntarily submitted to a review committee before publication, to determine whether the data should be withheld on national security grounds. The academy has to agree to accept a request that it nominate two members of the review committee, a move which could be taken as endorsing the idea

\title{
Harvard guidelines for avoiding fraud
}

\section{Washington}

A national conference involving both the National Institutes of Health (NIH) and the nation's research universities should be convened to consider a number of "unanswered questions" about dealing with suspicions of falsified research data, according to a committee of inquiry set up by Harvard Medical School to investigate the circumstances surrounding the admitted fabrication of data by a scientist studying the prevention of heart attacks (see Nature 24/31 December 1981, p.584).

The committee, chaired by Dr Richard S. Ross, dean of Johns Hopkins Medical School, has given its general approval of steps taken by the medical school after colleagues discovered that $\mathrm{Dr}$ John $\mathrm{R}$. Darsee was faking some of the raw data in an experiment in May 1981.

In its report, which was published in Boston on Monday, the committee describes how Dr Darsee was stripped of his position as a research fellow, as well as being removed from staff positions at the Brigham and Women's Hospital, as soon as the fabrication of data had been confirmed, and that his NIH research fellowship was removed at the same time. The medical school denied on Monday that it had been wrong to keep Dr Darsee involved in research at another laboratory in Harvard, or that it had been slow to raise public warning signals about his research, claiming that it had been some time before an internal investigation revealed just how extensive the fabrication of data may have been, and that up to that point Dr Darsee had gained a reputation as a talented and hard-working research worker.

The report of the review committee, which was set up at the invitation of the dean of Harvard Medical School, Dr Daniel Tosteson, says that it considers the medical school's response to have been appropriate for what was known at the time.

The committee makes two specific recommendations to the medical school. First, it should establish a committee of senior faculty members that can be called upon to investigate any suspicion of fraudulent data gathering. And second, the medical school should improve the internal communication system, so that people can be informed confidentially if a research worker under suspicion in another department has any connection with their own research. In the case of Dr Darsee, colleagues in the laboratory in which he was allowed to continue working were not aware of the charges made against him elsewhere in the medical school.

The committee also makes some general suggestions about how the scientific community might take steps to make it harder for an individual to publish false results. For example, it criticizes the practice of publishing small batches of research findings in a number of different publications, rather than concentrating them in a single, major publication, more likely to receive close scrutiny from the scientific community.

The committee also suggests that laboratories should agree on explicit procedures for data gathering, storage and analysis, and that these should be written up and be generally available to research workers. In Dr Darsee's case, he was unable to produce much of the raw data on which some of his research results were based, although the committee found that it was general practice in the laboratory that such data should be preserved.

Finally, the review committee suggests a national conference to look at the whole area of the falsification of research. Topics which it says a conference might address would include what the responsibility of an institution discovering dishonesty among its research staff should be with respect to other institutions, the scientific and medical community and the general public.

David Dickson 